\title{
Pengaruh Tepung Kiambang (Salvinia molesta) Terfermentasi dalam Ransum terhadap Karkas Itik Peking (Anas platyrhynchos domesticus)
}

\section{The Effect of Fermented Kiambang Flour (Salvinia molesta) in Rations on Peking Duck (Anas platyrhynchos domesticus) Carcasses}

\author{
N N E Sulistyawati ${ }^{1}$, Nurhayati ${ }^{1 *}$, dan I Panjaitan ${ }^{1}$ \\ ${ }^{1}$ Jurusan Peternakan Politeknik Negeri Lampung, \\ Jln. Soekarno Hatta No 10 Rajabasa Bandar Lampung, 35144 \\ * E-mail korespondensi: nurhayatipoltek@yahoo.com
}

\begin{abstract}
This study aims to analyze the use of fermented kiambang flour (Salvinia molesta) on rations against the quantity of peking duck carcasses. This research was conducted in the livestock cage of Lampung State Polytechnic. The research method carried out is a descriptive method. Data collection is done by taking samples from controls and treatment with a total of 15 ducks each at the end of maintenance. The result the treatment given in addition to 15\% fermented kiambang flour in rations produces carcass weight $(714.26 \mathrm{~g})$, carcass percentage (52.49\%), chest percentage (29.08\%), thigh percentage (26.37\%), winged percentage (16.92 $\%$ ) and abdominal fat percentage $(0.77 \%)$. Addition $15 \%$ fermented kiambang flour not affect to carcass weight, carcass percentage, chest percentage, winged percentage, and abdominal fat percentage.
\end{abstract}

Keywords: carcass, fermentation, kiambang, peking duck

Diterima: 20 September 2020, disetujui 15 Desember 2020

\section{PENDAHULUAN}

Ternak Itik merupakan salah satu sumber daya genetik yang cukup tinggi keanekaragamannya, baik dalam hal jenis maupun potensi produksinya. Ternak itik juga mempunyai potensi untuk dikembangkan karena memiliki daya adaptasi yang cukup baik. Itik memiliki banyak kelebihan dibandingkan ternak unggas lainnya, diantaranya adalah ternak itik lebih tahan terhadap penyakit seperti itik peking.

Itik peking merupakan salah satu jenis itik yang potensial sebagai itik pedaging dengan penampilan warna bulu putih, paruh dan shank kuning, bertubuh gempal (Agriflo, 2012). Umur 7-9 minggu bobot badan itik peking jantan 3,500-4,000 g/ekor, betina 3,000-3,500 g/ekor (Adzitey, 2011). Pertumbuhan itik peking cepat karena mampu mengkonsumsi ransum dalam jumlah banyak (Wakhid, 2013). Secara anatomi, itik memiliki paruh lebar, pipih dengan ujung tumpul (Ranto dan Sitanggang, 2005).

Kiambang merupakan gulma air yang hidup terapung pada permukaan air, banyak terdapat di selokan, parit, sawah, kolam, danau atau sungai dengan aliran air yang lambat dan saluran irigasi. Kiambang mudah hidup di daerah yang memiliki volume air banyak dan kiambang memiliki tingkat pertumbuhan yang cepat. Di daerah Provinsi Lampung belum ada pemanfaatan kiambang sebagai bahan pakan untuk ternak, terutama ternak unggas. Kandungan yang terdapat pada kiambang berpotensi sebagai bahan pakan untuk ternak unggas, namun tingginya serat kasar pada kiambang menjadi masalah untuk diberikan keternak unggas secara langsung. 
Ternak itik merupakan salah satu jenis unggas air (water fowl) karena unggas ini suka berenang di perairan. Itik keturunan Mallard di Indonesia dikenal dengan nama yang sesuai dengan tempat keberadaannya, seperti itik tegal, itik bali, itik alabio dan itik mojosari. Umur potong itik Peking bervariasi antara 8-10 minggu (Setioko, 2003).

Kiambang mengandung protein kasar 15,9\%, lemak kasar 2,1\%, Ca 1,27 \%, dan P 0,789 \%, tetapi kandungan serat kasarnya tinggi yaitu sebesar 16,8 \% (Rosani, 2002). Setiowati (2001), telah melaporkan bahwa kandungan energi metabolisme kiambang adalah $2200 \mathrm{kkal} / \mathrm{kg}$. Penggunaan tepung kiambang terfermentasi dalam pakan itik peking sebanyak $15 \%$ pada perlakuan. Penelitian tentang pemanfaatan kiambang terfermentasi kearah karkas masih sedikit. Sehingga perlu adanya penelitian ini yang memanfaatkan kiambang terfermentasi untuk mengukur kuantitas karkas itik peking. Penelitian ini bertujuan untuk menganalisis penggunaan tepung kiambang (Salvinia Molesta) terfermentasi dalam ransum terhadap kuantitas karkas.

\section{METODE PENELITIAN}

Penelitian ini dilaksanakan di Laboratorium dan Kandang Politeknik Negeri Lampung. Alat yang digunakan pada penelitian ini yaitu lampu, brooder, tempat pakan dan minum itik, timbangan digital, kompor, panci, saringan, baskom. Bahan yang digunakan pada penelitian ini yaitu DOD itik peking, kiambang, molasses, ragi tempe, pakan komersil, sekam, desinfektan, vaksin.

\section{Metode Penelitian}

Metode penelitian ini adalah percobaan lapang dan dianalisis secara deskriptif dengan menggunakan 2 perlakuan pakan. Perlakuan pakan terdiri dari P0 dan P1. P0 adalah pakan $100 \%$ pakan komersial (pakan kontrol) dan P1 adalah pakan dengan komposisi $85 \%$ pakan komersial dan $15 \%$ kiambang terfermentasi. Itik sebanyak 80 ekor di bagi menjadi 2 kelompok dengan setiap kelompok terdiri dari 40 ekor, perlakuan pemberian pakan pada itik dilakukan pada itik umur 8 hari dan pengambilan data sampel dilakukan pada umur 56 hari.

\section{Proses Fermentasi}

Kiambang fase 3 yang basah dikeringkan dengan sinar matahari, setelah kering kemudian digiling halus menjadi tepung. Kiambang tersebut dicampur dengan molases dengan perbandingan $1 \mathrm{~kg}$ kiambang dicampur dengan dua sendok makan molases. Setelah molases tercampur rata dengan kiambang, kiambang tersebut dikukus selama $1 / 2$ jam dan dibiarkan dingin. Setelah dingin, kiambang difermentasi dengan mencampurkannya dengan ragi tempe (1 kg kiambang : $18 \mathrm{~g}$ ragi tempe) dan dimasukkan ke dalam bak fermenter dan ditutup dengan plastik. Proses fermentasi berlangsung secara anaerob selama 7 hari. Setelah dilakukan fermentasi selama 7 hari, kiambang kemudian dicetak menjadi butiran-butiran pellet menggunakan gilingan daging yang dimodifikasi, kemudian dikeringkan menggunakan panas matahari (Zaman, et al. 2013).

\section{Pelaksanaan Penelitian}

Tahapan penelitian yang dilakukan meliputi proses fermentasi, persiapan kandang, kegiatan saat DOD tiba, dan aktivitas rutin.

\section{Pengarkasan}

Sebelum pemotongan itik dipuasakan selama \pm 8 jam dari pemberian pakan dan minum untuk menghindari bias akibat isi saluran pencernaan. Kemudian itik ditimbang untuk mengetahui bobot hidupnya. Pemotongan itik dilakukan pada bagian arteri karotis, vena jugularis, tenggorokan dan esophagus. Setelah darah dikeringkan selama \pm 3 menit. Pencabutan bulu di lakukan dengan cara mecabut semua bulu yang 
melekat pada itik. Selanjutnya dilakukan pengeluaran jeroan, kepala, leher dan kakinya dipotong sehingga yang ada hanya bagian karkas. Karkas yang diperoleh ditimbang dengan timbangan digital.

\section{Variabel yang Diamati dan Analisis Data}

Variabel yang diamati dalam penelitian adalah bobot karkas, persentase karkas, persentase bagianbagian karkas, dan lemak abdominal. Data yang diperoleh dianalisa secara deskriptif.

\section{HASIL DAN PEMBAHASAN}

Rataan bobot karkas, persentase karkas, persentase dada, persentase paha, persentase sayap dan persentase lemak abdominal disajikan pada Tabel 1.

Tabel 1. Rataan hasil data kuantitas karkas

\begin{tabular}{lcc}
\hline \multicolumn{1}{c}{ Variabel } & P0 & P1 \\
\hline Bobot Karkas (gram) & 737,20 & 714,26 \\
Persentase karkas (\%) & 51,52 & 52,49 \\
Persentase dada (\%) & 29,50 & 29,08 \\
Persentase paha (\%) & 27,17 & 26,37 \\
Persentase sayap (\%) & 17,05 & 16,92 \\
Persentase lemak abdominal (\%) & 0,79 & 0,77 \\
\hline
\end{tabular}

\section{Bobot Karkas}

Berdasarkan Tabel 1, dapat dilihat bahwa rata-rata bobot karkas pada P0 (737,2 g) sedangkan pada P1 $(714,26 \mathrm{~g})$, jika dilihat dari dua rataan tersebut terdapat selisih bobot karkas sebesar 22,94 g. Rataan bobot karkas P0 angkanya lebih besar dibandingkan dengan P1 (P0 > P1). Hal ini disebabkan oleh kandungan nutrisi pakan pada $\mathrm{P} 0$ secara kandungan energi metabolis, protein lebih tinggi dibandingkan P1, sedangkan serat kasar pada P0 lebih rendah dibandingkan dengan P1.

Imbangan energi dan protein yang lebih tinggi akan meningkatkan konsumsi pakan pada itik. Hal ini sesuai dengan pendapat (Kong and Adeola, 2010) bahwa Konsumsi pakan sangat ditentukan oleh kandungan protein dalam pakan karena sangat erat kaitannya terhadap proporsi ketersediaan asam amino esensial yang dibutuhkan ternak. Sehingga dapat dijelaskan bobot karkas yang tinggi diakibatkan oleh konsumsi pakan dengan kandungan protein yang tinggi.

Pakan merupakan salah satu faktor yang berpengaruh terhadap bobot karkas. Bobot karkas dipengaruhi mutrisi pakan yang dikonsumsi seperti kandungan nutrisi protein. Semakin tinggi kandungan proteinnya maka akan semakin baik pula untuk pertumbuhan ternaknya. Hal ini sesuai dengan pendapat Subekti et al. (2012) menyatakan bahwa bobot karkas yang dihasilkan dipengaruhi oleh beberapa faktor yaitu umur, jenis kelamin, bobot potong, besar perlemakan, kualitas dan kuantitas ransum serta strain yang dipelihara. Kandungan nutrisi protein pada P0 yaitu 19-21 \% sedangkan pada P1 yaitu 16,80-18,50 \% sehingga berat karkas pada P0 lebih besar dibandingkan P1.

\section{Persentase Karkas}

Berdasarkan Tabel 1, dapat dilihat bahwa rata-rata persentase karkas pada P0 $(51,52 \%)$ sedangkan pada P1 (52,49 \%), jika dilihat dari dua rataan tersebut terdapat selisih persentase karkas sebesar 0,197\%. Rataan persentase karkas pada P0 angkanya lebih kecil dibandingkan dengan P1 (P0 < P1). Hal ini disebabkan oleh rataan bobot karkas yang dihasilkan $\mathrm{P} 1$ berbanding lurus dengan rataan bobot hidup $\mathrm{P} 1$, sehingga persentase karkas P1 yang diperoleh lebih tinggi dibandingkan P0.

Bobot potong merupakan salah satu faktor yang mempengaruhi persentase karkas. Hal ini sesuai dengan pendapat Dewanti et al. (2013) bahwa bobot potong atau bobot hidup akan berpengaruh pada persentase karkas 
yang dihasilkan. Bobot potong merupakan berat hidup itik sebelum dipotong yang sebelumnya sudah dipuasakan selama 8--12 jam.

\section{Persentase dada}

Berdasarkan Tabel 1, dapat dilihat bahwa rata-rata persentase dada pada P0 $(29,50 \%)$ sedangkan pada P1 (29,08 \%), jika dilihat dari dua rataan tersebut terdapat selisih persentase dada sebesar 0,42 \%. Rataan persentase dada pada P0 angkanya lebih besar dibandingkan dengan P1 (P0 > P1). Hal ini disebabkan oleh bobot potong yang secara tidak langsung akan mempengaruhi berat karkas dan bagian-bagian karkas. Hal ini sesuai dengan pendapat Soeparno (1994) bahwa ada hubungan yang erat antara bobot karkas dan persentase bagian-bagian karkas dengan bobot potong, sehingga apabila dari hasil rataan bobot potong dan bobot karkas didapat hasil yang tidak jauh berbeda.

\section{Persentase paha}

Berdasarkan Tabel 1, dapat dilihat bahwa rata-rata persentase paha pada P0 $(27,17 \%)$ sedangkan pada P1 $(26,37 \%)$, jika dilihat dari dua rataan tersebut terdapat selisih persentase paha sebesar $0,80 \%$. Rataan persentase paha pada P0 angkanya lebih besar dibandingkan dengan P1 (P0 > P1). Perbedaan yang terjadi tersebut dipengaruhi oleh faktor pakan dan bobot potong. Hal ini secara tidak langsung akan mempengaruhi bobot karkas dan juga persentase bagian-bagian karkasnya. Hal ini sesuai dengan pendapat Soeparno (1994) bahwa ada hubungan yang erat antara bobot karkas dan persentase bagian-bagian karkas dengan bobot potong, sehingga apabila dari hasil analisis bobot potong dan bobot karkas didapat hasil yang tidak jauh berbeda.

Paha merupakan bagian karkas yang memiliki perdagingan yang tebal selain dada. Hal ini sesuai dengan pendapat Putra et al. (2015) tempat deposit daging pada karkas itik yang paling banyak selain bagian dada yaitu bagian paha.

\section{Persentase Sayap}

Berdasarkan Tabel 1, dapat dilihat bahwa rata-rata persentase sayap pada P0 $(17,05 \%)$ sedangkan pada P1 (16,92 \%), jika dilihat dari dua rataan tersebut terdapat selisih persentase sayap sebesar $0,13 \%$. Rataan persentase sayap pada $\mathrm{P} 0$ angkanya lebih besar dibandingkan dengan $\mathrm{P} 1$ (P0 > P1). Faktor yang mempengaruhi persentase sayap yaitu persentase karkasnya. Hal ini sesuai dengan pernyataan dari Daud et al. (2016) yang menyatakan bahwa persentase sayap pada itik, entok dan hasil persilangannya mengalami peningkatan sesuai dengan bertambahnya bobot potong karkas.

Sayap merupakan bagian karkas yang memiliki daging yang sedikit dan memiliki pertulangan yang cukup banyak. Hal ini sesuai dengan pendapat Syah et al. (2016) sayap adalah bagian karkas yang lebih banyak mengandung jaringan tulang dibandingkan jaringan ototnya.

\section{Persentase Lemak Abdominal}

Berdasarkan Tabel 1, dapat dilihat bahwa rata-rata persentase lemak abdominal pada P0 $(0,79 \%)$ sedangkan pada P1 $(0,77 \%)$, jika dilihat dari dua rataan tersebut terdapat selisih persentase lemak abdominal sebesar 0,02\%. Rataan persentase lemak abdominal pada P0 angkanya lebih besar dibandingkan dengan P1 $(\mathrm{P} 0>\mathrm{P} 1)$. Rendahnya persentase lemak abdominal pada itik peking ini diduga karena bobot hidup atau potong yang rendah. Hal ini sesuai dengan Dewanti et al. (2013) bahwa berat lemak abdominal cenderung meningkat dengan bertambahnya bobot hidup. Hasil penelitian ini, rataan bobot hidup itik pada P0 lebih tinggi dibandingkan dengan P1, sehingga bobot lemak abdominal yang dihasilkan pada P0 lebih tinggi dibanding dengan P1. Penyebab lain yang membuat persentase lemak abdominal pada P0 lebih tinggi dibandingkan dengan P1 yaitu kandungan nutrisi ransum P0 lebih tinggi dibandingkan dengan P1, sehingga jika kandungan energi di dalam ransum tinggi makan akan terjadi penumpukan energi yang disimpan sebagai lemak. Hal ini 
sesuai dengan Kurtini et al. (2011) menyatakan besar energi akan diikuti dengan semakin besar lemak tubuh yang dihasilkan.

Berat lemak abdominal itik dapat diketahui dengan cara menimbang lemak yang didapat dari lemak yang berada pada sekeliling gizzard dan lapisan yang menempel antara otot abdominal serta usus dan selanjutnya ditimbang (Salam et al., 2017).

\section{KESIMPULAN}

Dari hasil penelitian yang telah dilakukan dapat disimpulkan bahwa penggunaan $15 \%$ tepung kiambang terfermentasi dalam ransum tidak memiliki pengaruh terhadap bobot karkas, persentase karkas, persentase dada, persentase sayap, dan lemak abdominal itik peking

\section{DAFTAR PUSTAKA}

Agriflo. 2012. Itik Peking. Penebar Swadaya. Jakarta.

Adzitey, A. 2011. Duck production: has a potential to reduce poverty among rural households in asian communities-a review. Journal of World's Poultry Research J. World's Poult. Res, 1(1): 7-10.

Daud, M., Mulyadi, M., dan Fuadi, Z. 2016. Persentase karkas itik Peking yang diberi pakan dalam bentuk wafer ransum komplit mengandung limbah kopi. Jurnal Agripet. 16(1) : 62-68.

Dewanti, R., M. Irham, dan Sudiyono. 2013. Pengaruh penggunaan enceng gondok (Eichornia crassipes) terfermentasi dalam ransum terhadap persentase karkas, non-karkas, dan lemak abdominal itik lokal jantan umur delapan minggu. Buletin Petenakan. 37(1): 19-25.

Kong, C. dan Adeola, O. 2010. Apparent ileal digestibility of amino acids in feedstuffs for White Pekin ducks. Poultry Science. 89(3), pp. 545-550. doi: 10.3382/ps.2009-00485.

Putra, A., Rukmiasih, R., dan R. Afnan. 2015. Persentase dan kualitas karkas itik Cihateup-Alabio (CA) pada umur pemotongan yang berbeda. Jurnal Ilmu Produksi dan Teknologi Hasil Peternakan. 3(1) : 27-32.

Ranto dan M. Sitanggang. 2005. Panduan Lengkap Beternak Itik. Penebar Swadaya, Jakarta

Rosani, U. 2002. Performa Itik Lokal Jantan Umur 4-8 Minggu dengan Pemberian Kiambang (Salvinia Molesta) dalam Ransumnya. Skripsi. Jurusan Ilmu Nutrisi dan Makanan Ternak, Fakultas Peternakan Institut Pertanian Bogor. Bogor.

Setioko, L.H. Prasetyo, D.A. Kusumaningrum, dan S. Sopiana. 2004. Daya tetas dan kinerja pertumbuhan itik Pekin X Alabio (PA) sebagai induk itik pedaging. Pros. Seminar Nasional Teknologi Peternakan dan Veteriner, Bogor, 4-5 Agustus 2004. Puslitbang Peternakan. hlm. 569-573.

Setiowati, A.N. 2001. Pengukuran Retensi Nitrogen dan Energi Metabolis Kiambang (Salvinia molesta) pada Itik Lokal Jantan. Fakultas Peternakan, Institut Pertanian Bogor. Skripsi. Bogor

Subekti, K., H. Abbas, dan K.A. Zura. 2012. Kualitas karkas (berat karkas, persentase karkas, dan lemak abdomen) ayam broiler yang diberi kombinasi CPO (crude palm oil) dan vitamin C (ascorbic acid) dalam ransum sebagai anti stress. Jurnal Peternakan Indonesia. 14 (3) : 447453.

Salam, S., Fatahilah, A., Sunarti, D., dan Isroli, I., 2017. Berat karkas dan lemak abdominal ayam broiler yang diberi tepung jintan hitam (Nigella sativa) dalam ransum selama musim panas. Sains Peternakan: Jurnal Penelitian Ilmu Peternakan. 11(2) : 84-90.

Soeparno, 1994. Ilmu dan Teknologi Daging. Gadjah Mada University Press,. Yogyakarta. 
Sulistyawati dkk. : Pengaruh Tepung Kiambang (Salvinia molesta) Terfermentasi dalam Ransum terhadap Karkas Itik Peking (Anas platyrhynchos domesticus)/Peterpan 2 (2): 30-35

Syah, S., Daud, M., dan Latif, H., 2016. Evaluasi produksi dan persentase karkas Itik peking dengan pemberian pakan fermentasi probiotik. Jurnal Ilmiah Mahasiswa Pertanian: 1(1) : 719-730.

Wakhid, A. 2013. Beternak Itik. Agromedia. Jakarta.

Zaman, Q., Suparno, G., dan Hariani, D. 2013. Pengaruh kiambang (Salvinia molesta) yang difermentasi dengan ragi tempe sebagai suplemen pakan terhadap peningkatan biomassa ayam pedaging. LenteraBio: Berkala Ilmiah Biologi. 2(1): 131-137. 